\title{
Desfluranın Aynı Konsantrasyonda Fakat Farklı Akımlarda Kullanılması Oksidatif Stresi Değiștiştirir mi? Hayvan Deneyi
}

Çiğdem ÜNAL KANTEKIN ${ }^{1}$, Müge ÇAKIRCA ${ }^{2}$, Ferda YAMAN $^{3}$, Ayșe Yeșim GÖÇMEN $^{4}$

\begin{abstract}
Öz
İnhalasyon anesteziklerinin oksidatif stres ve serbest radikallerin oluşumunda etkili olduğu bilinmektedir. Bu çalışmanın amacı, desfluranın bu etkilerini araştırmak ve farklı akımlarda oluşan değişiklikleri saptamaktır. Fareler üç gruba ayrıldı (10 fare / grup). Birinci grup kontrol grubu idi. İkinci grupta, ketamin ile sedasyon sağlanan farelere bir cam kutuda \% 100 oksijen içerisinde \% 6 konsantrasyonda, 20 dakika boyunca, 8 lt / dk akış hızında desfluran verildi. Üçüncü grupta bir cam kutu içerisinde ketamin ile sedasyon sağlanmış farelere, \% 100 oksijen içerisinde \% 6 konsantrasyonda, 20 dakika boyunca, 2 lt / dk akış hızında desfluran verildi. Biyokimyasal parametreler ölçüldü. Serum, beyin, karaciğer dokusu MDA ve SOD düzeyleri yüksek akım grubunda kontrol ve düşük akım grubundan anlamlı olarak daha yüksek bulundu. Her iki gruba göre serum GPx düzeyleri yüksek akım grubunda anlamlı olarak düşüktü. Serum, karaciğer ve beyin dokusunda ADMA düzeyleri yüksek akım grubunda anlamlı olarak yüksek bulundu. Her üç grup arasında serum 8-OHdG seviyelerinde anlamlı fark yoktu. Beyin ve karaciğer dokusu 8-OHDG düzeyleri her iki grupta kontrol grubuna göre daha yüksekti. Desfluran anestezi modelinde, desfluranın aynı konsantrasyonlarda düşük akımda kullanıldığında oksidatif stresi azalttığı, yüksek akımda kullanıldığında ise oksidatif stresi arttırdığı görülmüştür.
\end{abstract}

Yayın Bilgisi

Gönderi Tarihi: 30.11 .2018

Kabul Tarihi: 30.12 .2018

Online Yayın Tarihi: 31.12.2019

DOI: $10.26453 /$ otjhs.490617

Sorumlu Yazar

Çiğdem ÜNAL KANTEKIN

Atatürk Yolu 7. Km 66100 - Yozgat /

Turkey

Tel: $\quad+903542127060$

Fax: $\quad+903542123739$

E-Mail: drcgdm@hotmail.com

Anahtar kelimeler: Desfluran, oksidatif stres, düşük akım, yüksek akım

\section{Does the Application of Desflurane at The Same Concentration by Different Flows Change the Oxidative Stress? Animal Experiment}

Çiğdem ÜNAL KANTEKIN ${ }^{1}$, Müge ÇAKIRCA ${ }^{2}$, Ferda YAMAN $^{3}$, Ayșe Yeșim GÖÇMEN $^{4}$

\begin{abstract}
It is known that inhalation anesthetics are effective in the formation of oxidative stress and free radicals. The purpose of this study is to investigate these effects of desflurane and to detect changes in different flows. The rats were divided into three groups (10 mice/group). The first group was the control group. In the second group, mice were sedated with ketamine and given desflurane at a concentration of $6 \%$ in a $100 \%$ oxygen flow at a flow rate of $8 \mathrm{lt} /$ $\min$ in a glass box for 20 minutes. The third group was comprised of ketamine-sedated mice that were given desflurane at a concentration of $6 \%$ in a $100 \%$ oxygen flow at a flow rate of $2 \mathrm{lt} / \mathrm{min}$ in a glass box for 20 minutes. Biochemical parameters were measured using commercial kits. Serum, brain, liver tissue MDA and SOD levels were significantly higher in the high flow group than in the control and low flow group. Serum GPx levels were significantly lower in the high flow group compared to both groups. ADMA levels in the serum, liver, and brain tissue were significantly higher in the high flow group. There was no significant difference in serum 8-OHdG levels between all three groups. Brain and liver tissue 8-OHDG levels were higher in both groups than control group. It has been observed that the use of low flow fresh gas even in the same concentrations of desflurane anesthesia models decreases oxidative stress whereas the use of high flow increases oxidative stress.
\end{abstract}

Article Info

Received: 30.11 .2018

Accepted: 30.12 .2018

Online Published: 31.12.2019

DOI: $10.26453 /$ otjhs.490617

Corresponding Author Çiğdem ÜNAL KANTEKIN Atatürk Yolu 7. Km 66100 - Yozgat / Turkey

Tel: $\quad+903542127060$

Fax: $\quad+903542123739$

E-Mail: drcgdm@hotmail.com

Keywords: Desflurane, oxidative stress, low flow, high flow

${ }^{1}$ Department of Anesthesiology, Bozok University, Faculty of Medicine, Yozgat, Turkey

${ }^{2}$ Department of Anesthesiology, Ministry of Health Numune Training and Research Hospital, Ankara,Turkey

${ }^{3}$ Department of Anesthesiology, Güven Hospital, Ankara, Turkey

${ }^{4}$ Department of Biochemistry, Bozok University, Faculty of Medicine, Yozgat, Turkey

\section{INTRODUCTION}

Reactive oxygen species (ROS) as well as reduced antioxidant defense mechanisms have been suggested to play a role in humans and various animal models. ${ }^{1}$ It is also known that free radical formation and increased lipid peroxidation play a role in the pathogenesis of many diseases ${ }^{2}$. Studies on the role of anesthetics in the formation of free radicals 
and their protection against harmful effects are increasing day by day.

The various harmful effects of these damaging radicals on the body can be demonstrated by biochemical parameters. ${ }^{1}$ Malondialdehyde (MDA), an end product of oxidative stress, is MDA, which measures lipid peroxidation; glutathione peroxidase (GPx) and superoxide dismutase (SOD) are antioxidant compounds in which the amounts consumed in the measurement of oxidative stress are regarded as an indication; asymmetric dimethyl arginine-nitric oxide synthase inhibitor (ADMA) and 8-hydroxy2-deoxyguanosine $\quad(8-\mathrm{OHdG}) \quad$ are biochemical parameters used to measure tissue and DNA damage.

Desflurane is an inhalation anesthetic known to have effects on the immunity and oxidantantioxidant system which are frequently used in anesthesia. ${ }^{2}$ However, there is no article in the literature with regards to whether these effects vary when different flow rates are applied at the same concentration. ${ }^{3,4}$ In this experimental study, we aimed to investigate the effects of desflurane anesthesia applied in two different flows, on oxidative stress and antioxidant defense markers in blood and tissue samples.

\section{MATERIALS AND METHODS}

The study was carried out in the Kirlkkale University Experimental and Clinical Research Center with approval number 15/37
Dated 15.04.2015 from the Kirıkklale University Medical faculty Animal Studies Ethics Committee and was supported by the Bozok University Scientific Research Projects Unit (2015TF/A204). Thirty, C57BL/6, 6-8 week old female mice were used in the study.

\section{Animals and study protocol}

All the animals were fasted for $16 \mathrm{hrs}$, but still allowed free access to drinking tap water, before the commencement of our experiments C57BL/6, 6-8 week old female mice were randomly divided into 3 equal groups, each containing 10 mice.Group 1 (control group): Received ketamine for sedation. Group 2 (low flow): Received ketamine for sedation. Later, desflurane was inhalated for anesthesia at a concentration of $6 \%$ in a $100 \%$ oxygen flow at a flow rate of 2 lt / min for 20 minutes.

Group 3 (high flow): Received ketamine for sedation. Later, desflurane was inhalated for anesthesia at a concentration of $6 \%$ in a $100 \%$ oxygen flow at a flow rate of $8 \mathrm{lt} / \mathrm{min}$ for 20 minutes.

At the end (20 minutes) of anesthesia period, animals were sacrificed. Blood and tissue samples were removed, tissues were washed in ice-cold PBS and weighed.

\section{Serum and tissue preparation}

At the end of this study, samples of blood, liver and brain tissues of each mouse were taken. The mouse tissues were weighed and 
placed in tubes. Tissue MDA, GPx, SOD, ADMA, 8-OHDG levels were analyzed in the homogenates prepared by adding TrisHCI buffer $(\mathrm{pH}=7.4)$ at a rate of $1 / 10(\mathrm{~g} / \mathrm{h})$ on the homogenizer at the appropriate rate per minute. Blood was centrifuged at 3500 rpm at $+4^{\circ} \mathrm{C}$ for 15 minutes to obtain serum.

\section{Biochemical parameters}

The ELISA kits of Cayman Chemical Company, USA were used for determination of the serum and tissue activities of GPX (U/ml or $\mathrm{U} / \mathrm{mg}$ protein) and SOD (U/ml or $\mathrm{U} / \mathrm{mg}$ protein) and the concentrations of MDA (nmol $/ \mathrm{ml}$ or $\mu \mathrm{mol} / \mathrm{mg}$ protein), ADMA ( $\mu \mathrm{mol} / \mathrm{L}$ or $\mathrm{mmol} / \mathrm{mg}$ protein) and $8-\mathrm{OHdG}$ ADMA ( $\mathrm{ng} / \mathrm{ml}$ or $\mathrm{mmol} / \mathrm{g}$ protein) by using an ELISA reader (Absorbance Microplate Reader, BioTek ${ }^{\circledR}$, USA) following the manufacturer's protocol.

\section{Statistical analysis:}

Statistical analysis was performed using SPSS version 16.0. The results were expressed as mean \pm standard deviation. All data were analyzed using one-way analysis of variance (ANOVA) and Dunnett's t-test. $\mathrm{p}<0.05$ was considered statistically significant.

\section{RESULTS}

Differences in all parameters among study groups are shown in Table 1.

Serum MDA levels in the high flow group were significantly higher than MDA levels in both brain and liver tissues as well as MDA levels in the control and low flow group (Figure 1).

Serum, brain and liver tissue SOD levels were also significantly higher in the high flow group than in the other groups (Figure 2). Serum GPx levels were significantly lower in the high flow group compared to both groups. While there was no significant difference in brain and liver tissue GPx levels, serum GPx levels were lower in both groups than in the control group (Figure 3).

When ADMA levels were evaluated, serum, liver and brain ADMA levels were significantly higher in the high flow group than in the control and low flow group (Figure 4). There was no significant difference in serum $8-\mathrm{OHdG}$ levels between all three groups. On the other hand, compared to control mice, $8-\mathrm{OHdG}$ levels were higher in low and high flow mice brain and liver tissues, whereas there was no significant difference between low and high flow groups (Figure 5, Table 1).

\section{DISCUSSION}

Oxygen-derived free radicals are reactive, can be detoxified by endogenous antioxidants, which can also lead to cell death. General anesthetics inhibit free radical production by reducing the use of free oxygen and glucose and slowing the oxidative mechanism in the neutrophils. Antioxidant intravenous anesthetics, such as 
thiopental and propofol, directly removes reactive oxygen species and inhibits lipid peroxidation. $^{5}$ In contrast, inhalation anesthetics have been shown to produce reactive oxygen species, especially in the heart, which is presumably due to the inhibition of cardiac mitochondria. On the other hand, since these radicals are part of the signal cascade that leads to cardiac protection, low doses of inhaled anesthesia can have a paradoxically protective effect, while their use in high doses is detrimental. ${ }^{6}$ In this study, the effects of two different flow rate desflurane applicationson oxidative stress markers were investigated and it was aimed to investigate the alterations in these markers without changing desflurane concentration.

Membrane lipids are the cell elements that are most affected by the harmful effects of free oxygen radicals. The end product of lipid peroxidation, MDA (malondialdehyde), is used as a marker of oxidative stressinduced damage in biological systems. ${ }^{7,8}$ Savac1 et al divided laparoscopic surgery patients into 4 groups (desflurane and fentanyl, sevoflurane and fentanyl, sevoflurane and $\mathrm{N}_{2} \mathrm{O}$, desflurane and $\mathrm{N}_{2} \mathrm{O}$ ) and examined the preoperative, 6th hour and 24th hour postoperative MDA values. In both groups with desflurane, MDA levels were significantly higher at 6th and 24th hours than sevoflurane groups. $^{9}$ In a study performed, desfluran increased local and systemic oxidative stress more than sevoflurane and propofol, while in another study it was reported to be more antioxidant than sevoflurane. ${ }^{10}$ However, desflurane created a higher oxidative load than both with sevoflurane, and especially than opioid used with nitrogen. ${ }^{9-11}$ In this study, desflurane was found to increase systemic and local oxidative stress compared to the control group, and it was determined that using desflurane in high-flow oxygen caused more oxidative damage.

SOD is an enzyme that is an endogenous antioxidant defense initiator. If an electron is added to $\mathrm{O}^{-2}$ (superoxide dismutation) or $\mathrm{O}^{-2}$ is directly reduced, hydrogen peroxide is formed. The reaction takes place via the SOD enzyme. ${ }^{12}$ This reaction is also called the first defense against oxidative stress, because $\mathrm{O}^{-2}$ is a powerful initiator of chain reactions. This reaction keeps the $\mathrm{O}^{-2}$ levels in the cellular compartments under control. SOD enzyme is present in excess in the liver, adrenal gland, kidney, spleen and erythrocytes where the oxygen pressure is high. ${ }^{13}$ For this reason, we also evaluated the SOD levels in the liver. In our study, SOD enzyme levels in both liver and blood and brain tissues were significantly higher in the high flow group and while it was higher than the control group in the low flow group but still significantly lower than the high flow group. 
GPx (Glutathione peroxidase) is a localized antioxidant enzyme in the matrix of cytosol and mitochondria. Glutathione allows $\mathrm{H}_{2} \mathrm{O}_{2}$ and hydroperoxides $(\mathrm{ROOH})$ to be catalyzed as selenium-dependent or seleniumindependent. ${ }^{13}$ Serum GPx enzyme level in the high flow group was significantly lower than both groups. However, GPx levels in both groups were lower than in the control group, although there was no significant difference between low and high flow groups in brain and liver tissue GPx levels. We believe that this is due to the fact that very high levels of hydrogen peroxide inhibit GPx enzyme. This finding explains the significantly high levels of MDA and ADMA of which we evaluated the lipid peroxidation and $\mathrm{d}$-arginine-inducible $\mathrm{d}$-arginine dehydrogenase (DADH) activity.

Asymmetric dimethyl arginine (ADMA) is an endogenous Nitric Oxide Synthase Enzyme (NOS) inhibitor. ${ }^{14}$ While some of ADMA and LNMMA are removed from the kidneys, most of them are metabolized by digestion into citrulline and dimethylamine or monomethylamine through dimethyl arginine dimethylamino hydrolase (DADH). Inhibition of the DADH enzyme increases the concentration of ADMA, leading to a decrease in NO production. DADH activity, which is hypersensitive to oxidative stress, is reduced in cases of inflammation and oxidative stress. The inactivation of DADH enzyme result in impaired elimination of ADMA. The increase in ADMA levels also leads to a decline in NO production. ${ }^{15}$ When ADMA levels were evaluated, it was seen that in high flow group serum, liver and brain levels were significantly higher than control and low flow group.

Reactive oxygen metabolites, which are the natural end result of oxygen use, are attacking DNA as well as lipids, carbohydrates, proteins. DNA in every cell of the human body is exposed to free radical attack about 10.000 times a day. ${ }^{16}$ 8hydroxy-2'-deoxyguanosine $(8-\mathrm{OHdG})$ is the most common oxidative base damage product of ROM made in DNA, and its mutagenesis is well known. In our study, no significant difference was found in all three groups between the plasma 8-OHDG levels that were indicative of DNA damage. There was no significant difference in brain and liver tissue 8-OHdG levels between low and high flow groups while the levels were higher in both groups compared to the control group.

Excessive oxygen exposure results in hyperoxia which has been shown in cell culture and ischemia reperfusion studies to lead to an increase in reactive oxygen species. ${ }^{17-19}$ With the application of the inhalation anesthetic at high flow rates, the organism is exposed to more oxygen. Especially, in certain types of operations 
where the risk of ischemia-reperfusion injury is high, higher risk of oxidative damage may be associated with high flow anesthesia technique. ${ }^{7}$ In this study, we also think that the oxidative stress is caused not only by desflurane but by the increase in the amount of oxygen used. If the consumption of desflurane is considered to be constant, it is understood that the difference between the two groups may be due to hyperoxia, therefore, the use of high $\mathrm{FiO}_{2}$ should be avoided in anesthesia.

As a result, applying desflurane anesthesia in low flow reduces gas consumption, which might have economic and environmental advantages. This study showed that the use of low flow fresh gas even in the same concentrations of desflurane anesthesia models decreases oxidative stress whereas the use of high flow increases oxidative stress which can be considered as another advantage of at low flow desflurane anesthesia.

\section{REFERENCES}

1. Noeman SA, Hamooda HE, Baalash AA. Biochemical study of oxidative stress markers in the liver, kidney and heart of high fat diet induced obesity in rats. Diabetol Metab Syndr. 2011;3(1):17.

2. Zhang W, Liu M, Zang Z, et al. Effect of different anesthesia methods on erythrocyte immune function in mice. Asian Pac J Trop Med. 2013;6(12):995-998.
3. Türkan H, Aydın A, Sayal A, et al. The effect of sevoflurane and desflurane on markers of oxidative status in erythrocyte. Toxicol Ind Health. 2011; 27(2):181-186.

4. Schilling T, Kozlan A, Kretzschmar M, et al. Effects of propofol and desflurane anaesthesia on the the alveolar inflammatory response to one-lung ventilation. $\mathrm{Br} \mathrm{J}$ Anaesth. 2007;99(3):368-375.

5. Wilson JX, Gelb AW. Free Radicals, Antioxidants, and Neurologic Injury: Possible Relationship to Cerebral Protection by Anesthetics. J Neurosurg Anesthesiol. 2002;14(1):66-79.

6. Kevin LG, Novalija E, David F. Reactive Oxygen Species as Mediators of Cardiac Injury and Protection: The Relevance to Anesthesia Practice. Anesth Analg. 2005;101(5):1275-1287.

7. Zülfikaroğlu B, Koç M, Soran A, Isman FK, Cinel İ. Evaluation of oxidative stress in laparoscopic cholecystectomy. Surg Today. 2002;32(10):869-874.

8. Garg N, Singh R, Dixit J, Jain A, Tewari V. Levels of lipid peroxides and antioxidants in smokers and nonsmokers. J Periodontal Res. 2006;41(5):405-410.

9. Sivaci R, Kahraman A, Serteser M, Sahin DA, Dilek ON. Cytotoxic effects of volatile anesthetics with free radicals undergoing laparoscopic surgery. ClinBiochem. 2006;39(3):293-298. 
10. Allaouchiche B, Debon R, Goudable J, Chassard D, Duflo F. Oxidative stress status during exposure to propofol, sevoflurane and desflurane. Anesth Analg. 2001; 93(4): 981985.

11. Koksal GM, Sayilgan C, Aydin S, Uzun H, $\mathrm{Oz} \mathrm{H}$. The effects of sevoflurane and desflurane on lipid peroxidation during laparoscopic cholecystectomy. Eur J Anaesthesiol. 2004;21(3):217-220.

12. Halliwell B, Chirico S. Lipid peroxidation: its mechanism, measurement, and significance. Am J Clin Nutr. 1993;57(5):715-772.

13. Yu BP. Cellular defenses against damage from reactive oxygen species. Physiol Rev. 1994;74(1):139-162.

14. Aydın M, Erdoğmuş F, Armutçu F, Yiğitoğlu MR. Metabolism of Asymmetric Dimethylarginine (ADMA). Int J Basic Clin Med. 2013;1(1):61-66

15. Matsuguma K, Ueda S, Yamagishi S, et al. Molecular mechanism for elevation of asymmetric dimethylarginine and its role for hypertension in chronic kidney disease. J Am Soc Nephrol. 2006;17(8);2176-2183.

16. Ames BN, Shigenara MK. DNA damage by endogenous oxidants and mithogenesis as causes of aging and cancer molecular biology of free radical scavenging systems, $2^{\text {nd }}$ ed. New York: Cold Spring Harbor Laboratuary Pres; 1992.

17. Brueckl C, Kaestle S, Kerem A, et al. Hyperoxia-induced reactive oxygen species formation in pulmonary capillary endothelial cells in situ. Am J Respir Cell Mol Biol. 2006;34(4):453-463.

18. Fessel JP, Flynn CR, Robinson LJ, et al. Hyperoxia synergizes with mutant bone morphogenic protein receptor 2 to cause metabolic stress, oxidant injury, and pulmonary hypertension. Am J Respir Cell Mol Biol. 2013;49(5):778-787.

19. Stoner JD, Clanton TL, Aune SE, Angelos MG. $\mathrm{O}_{2}$ delivery and redox state are determinants of compartment-specific reactive $\mathrm{O}_{2}$ species in myocardial reperfusion. Am J Physiol Heart Circ Physiol. 2007;292(1):109-116. 


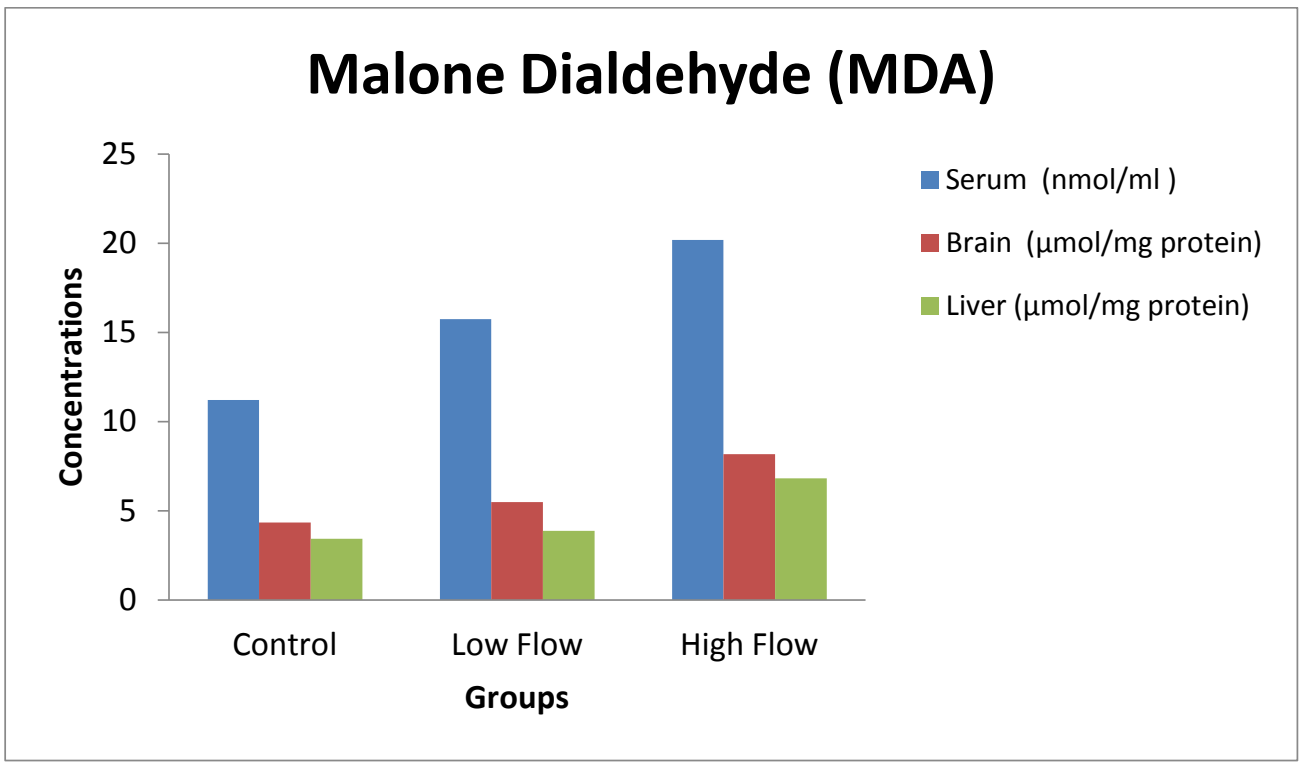

Figure 1. Serum, brain and liver MDA levels. 


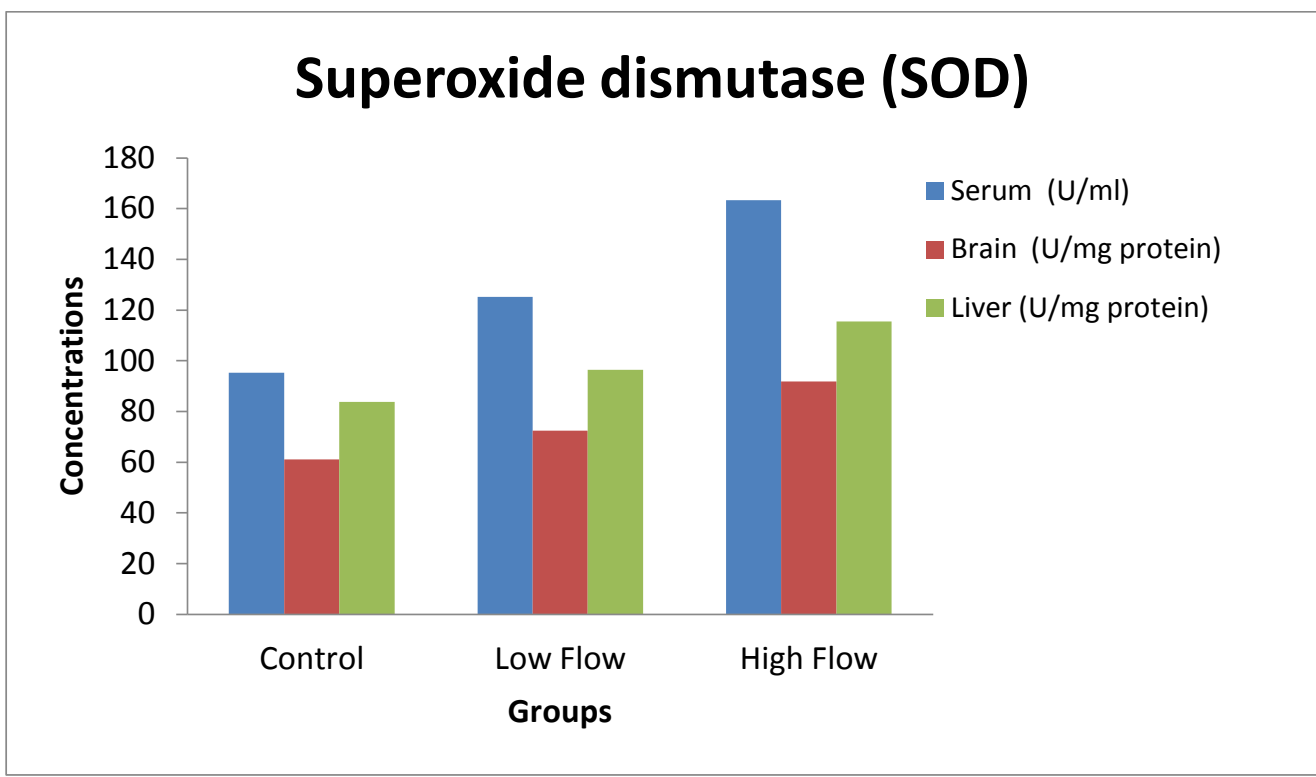

Figure 2. Serum, brain and liver SOD levels. 


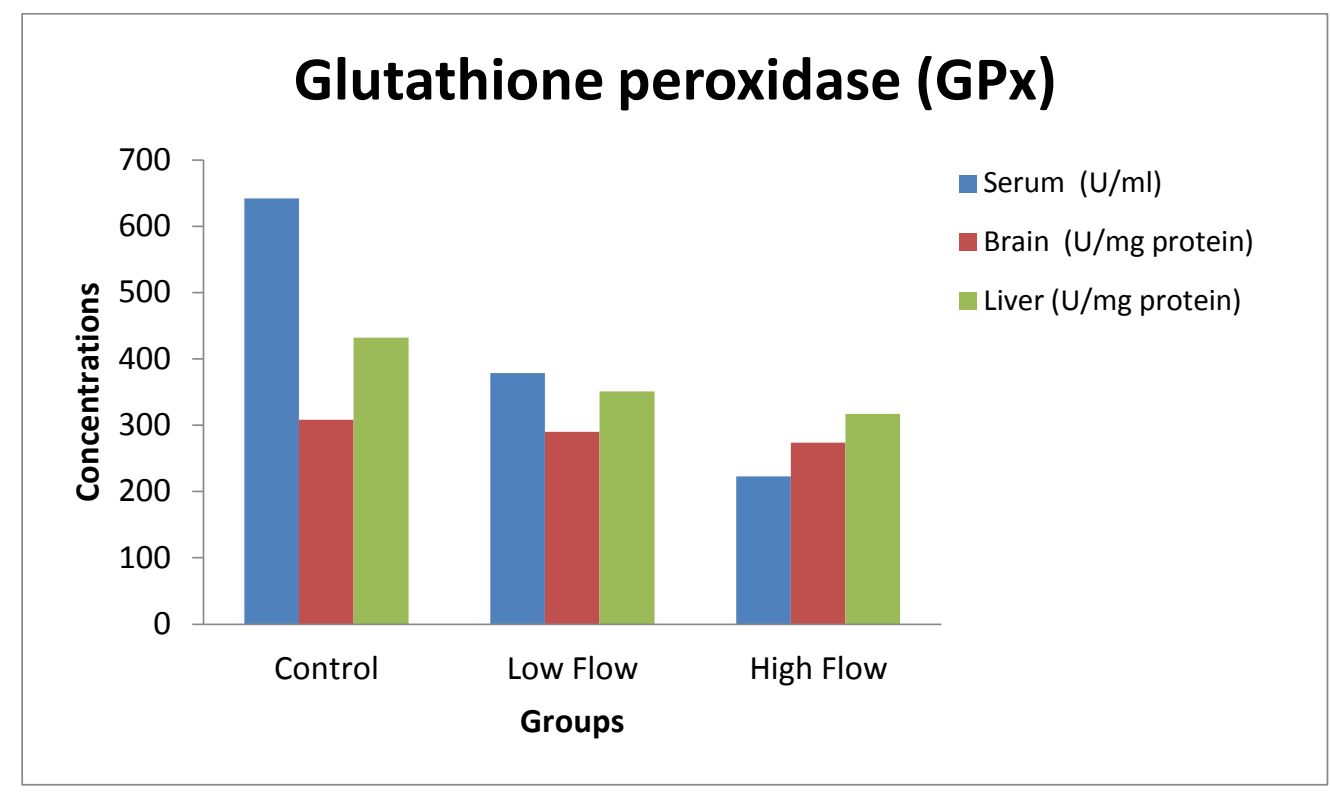

Figure 3. Serum, brain and liver GPx levels. 


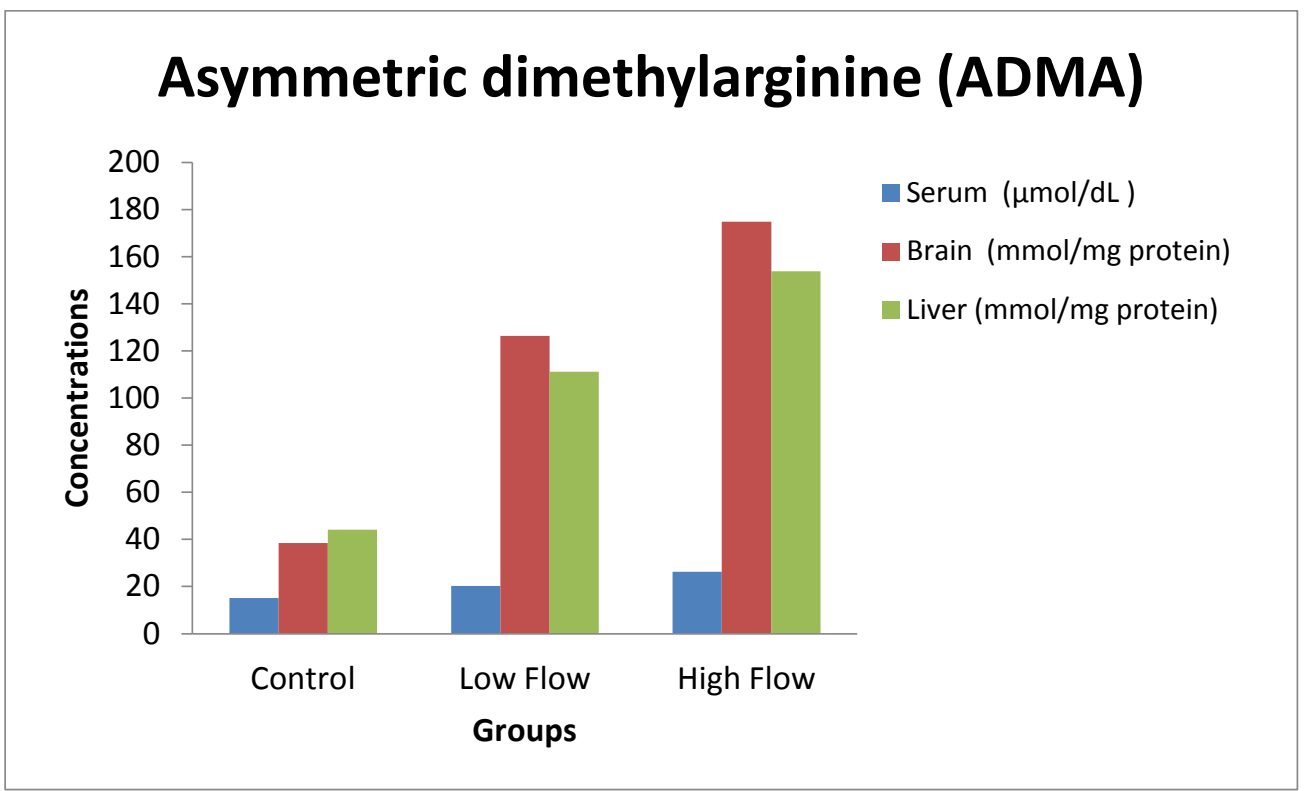

Figure 4. Serum, brain and liver ADMA levels. 


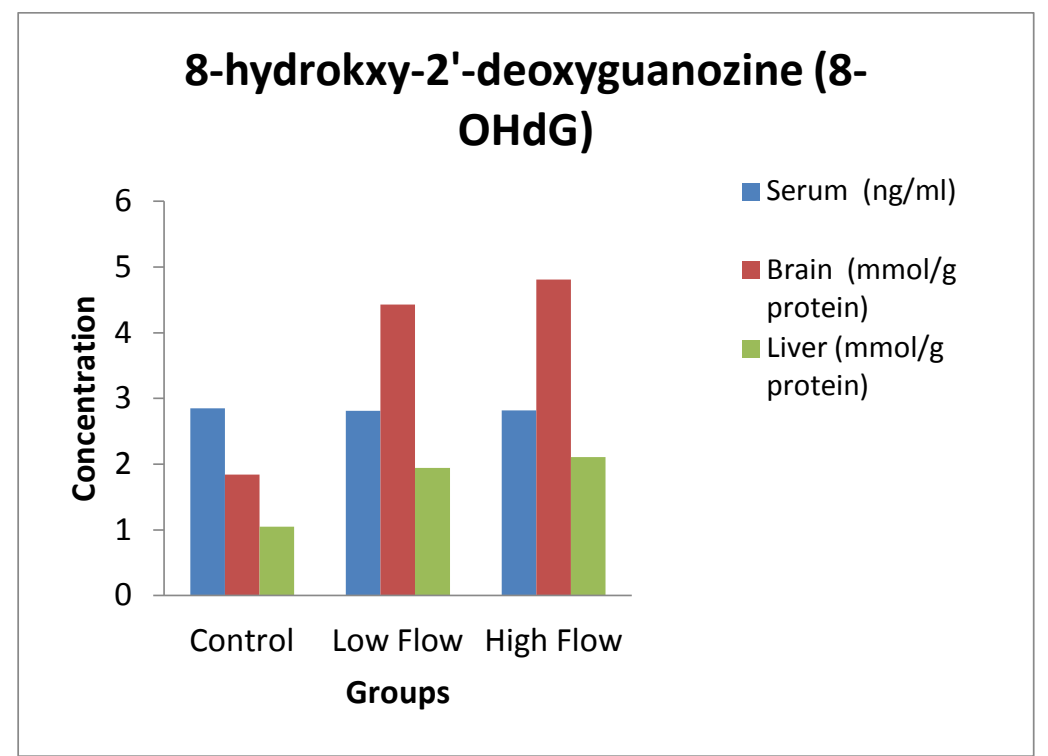

Figure 5. Serum, brain and liver $8-\mathrm{OHdG}$ levels. 
Table 1. MDA, ADMA, SOD, GPx, 8-OHdG levels of groups.

\begin{tabular}{|c|c|c|c|}
\hline Parameters & $\begin{array}{l}\text { Control } \\
\mathrm{N}=10\end{array}$ & $\begin{array}{l}\text { Low-flow } \\
\mathrm{N}=10\end{array}$ & $\begin{array}{l}\text { High-flow } \\
\mathrm{N}=10\end{array}$ \\
\hline $\begin{array}{l}\text { Serum MDA } \\
(\mathrm{nmol} / \mathrm{ml})\end{array}$ & $11.21 \pm 2.64$ & $\begin{array}{l}15.75 \pm 3.56 \\
\alpha: p<0.001\end{array}$ & $\begin{array}{l}22.19 \pm 6.51 \\
\beta: p<0.001 \\
\gamma: p<0.05\end{array}$ \\
\hline $\begin{array}{l}\text { Brain MDA } \\
(\mu \mathrm{mol} / \mathrm{mg} \text { protein) }\end{array}$ & $4.35 \pm 0.52$ & $\begin{array}{l}5.49 \pm 1.31 \\
\alpha: p<0.005\end{array}$ & $\begin{array}{l}9.18 \pm 0.87 \\
\beta: p<0.005 \\
\gamma: \text { n.s. }\end{array}$ \\
\hline $\begin{array}{l}\text { Liver MDA } \\
(\mu \mathrm{mol} / \mathrm{mg} \text { protein) }\end{array}$ & $3.44 \pm 0.41$ & $\begin{array}{l}3.87 \pm 0.53 \\
\alpha: p<0.05\end{array}$ & $\begin{array}{l}8.81 \pm 0.76 \\
\beta: p<0.001 \\
\gamma: p<0.001\end{array}$ \\
\hline $\begin{array}{l}\text { Serum ADMA } \\
(\mu \mathrm{mol} / \mathrm{L})\end{array}$ & $1.51 \pm 0.36$ & $\begin{array}{l}2.03 \pm 0.42 \\
\alpha: p<0.001\end{array}$ & $\begin{array}{l}4.62 \pm 0.82 \\
\beta: p<0.001 \\
\gamma: p<0.05\end{array}$ \\
\hline $\begin{array}{l}\text { Brain ADMA } \\
\text { (mmol/mg protein) }\end{array}$ & $38.48 \pm 11.18$ & $\begin{array}{l}126.37 \pm 32.67 \\
\alpha: p<0.001\end{array}$ & $\begin{array}{l}174.82 \pm 40.52 \\
\beta: p<0.001 \\
\gamma: p<0.001\end{array}$ \\
\hline $\begin{array}{l}\text { Liver ADMA } \\
\text { (mmol/mg protein) }\end{array}$ & $44.11 \pm 14.06$ & $\begin{array}{l}111.21 \pm 28.75 \\
\alpha: p<0.001\end{array}$ & $\begin{array}{l}153.84 \pm 35.66 \\
\beta: p<0.001 \\
\gamma: p<0.001\end{array}$ \\
\hline $\begin{array}{l}\text { Serum SOD } \\
(\mathrm{U} / \mathrm{ml})\end{array}$ & $163.30 \pm 6.45$ & $\begin{array}{l}125.20 \pm 9.88 \\
\alpha: p<0.001\end{array}$ & $\begin{array}{l}195.34 \pm 6.41 \\
\beta: p<0.001 \\
\gamma: p<0.001\end{array}$ \\
\hline $\begin{array}{l}\text { Brain SOD } \\
\text { (U/mg protein) }\end{array}$ & $81.92 \pm 3.47$ & $\begin{array}{l}72.40 \pm 3.48 \\
\alpha: p<0.001\end{array}$ & $\begin{array}{l}161.18 \pm 4.17 \\
\beta: p<0.001 \\
\gamma: p<0.001\end{array}$ \\
\hline $\begin{array}{l}\text { Liver SOD } \\
\text { (U/mg protein) }\end{array}$ & $115.45 \pm 13.32$ & $\begin{array}{l}96.42 \pm 6.71 \\
\alpha: p<0.001\end{array}$ & $\begin{array}{l}183.82 \pm 11.68 \\
\beta: p<0.001 \\
\gamma: p<0.001\end{array}$ \\
\hline $\begin{array}{l}\text { Serum GPx } \\
(\mathrm{U} / \mathrm{ml})\end{array}$ & $641.72 \pm 28.85$ & $\begin{array}{l}578.88 \pm 30.96 \\
\alpha: p<0.001\end{array}$ & $\begin{array}{l}422.57 \pm 46.35 \\
\beta: p<0.001 \\
\gamma: p<0.001\end{array}$ \\
\hline $\begin{array}{l}\text { Brain GPx } \\
\text { (U/mg protein) }\end{array}$ & $308.19 \pm 19.54$ & $\begin{array}{l}290.24 \pm 21.51 \\
\alpha: p<0.05\end{array}$ & $\begin{array}{l}273.49 \pm 51.66 \\
\beta: p<0.05 \\
\gamma: \text { n.s. }\end{array}$ \\
\hline $\begin{array}{l}\text { Liver GPx } \\
\text { (U/mg protein) }\end{array}$ & $432.01 \pm 58.09$ & $\begin{array}{l}351.03 \pm 47.78 \\
\alpha: p<0.001\end{array}$ & $\begin{array}{l}317.23 \pm 105.84 \\
\beta: p<0.001 \\
\gamma: \text { n.s. }\end{array}$ \\
\hline $\begin{array}{l}\text { Serum 8-OHdG } \\
(\mathrm{ng} / \mathrm{ml})\end{array}$ & $2.85 \pm 0.07$ & $\begin{array}{l}2.81 \pm 0.08 \\
\alpha: \text { n.s. }\end{array}$ & $\begin{array}{l}2.82 \pm 0.17 \\
\beta: n . s . \\
\gamma: n . s .\end{array}$ \\
\hline $\begin{array}{l}\text { Brain 8-OHdG } \\
\text { (mmol/g protein) }\end{array}$ & $1.84 \pm 0.46$ & $\begin{array}{l}4.43 \pm 0.98 \\
\alpha: p<0.001\end{array}$ & $\begin{array}{l}4.81 \pm 0.31 \\
\beta: p<0.001 \\
\gamma: \text { n.s. }\end{array}$ \\
\hline $\begin{array}{l}\text { Liver 8-OHdG } \\
\text { (mmol/g protein) }\end{array}$ & $1.05 \pm 0.30$ & $\begin{array}{l}2.94 \pm 0.43 \\
\alpha: \mathrm{p}<0.001\end{array}$ & $\begin{array}{l}3.11 \pm 0.13 \\
\beta: p<0.001 \\
\gamma: \text { n.s. }\end{array}$ \\
\hline
\end{tabular}

Data presented as mean $\pm S D ; n=10$ animals per group. The abbreviations are as in the text. n.s.; non-significant; $\alpha$, difference between the low flow group versus the control group; $\beta$, difference between the high flow group versus the control group; $\gamma$, difference between the high flow versus low flow group. 